\title{
Respon Tanaman Pakcoy (Brassica Rapa L.) terhadap Pupuk Pelengkap Cair pada Sistem Vertikultur
}

\author{
Dedi Sudarmaji, Ruswadi Muchtar, dan Ayu Vandira Candra Kusumah \\ Program Studi Agroteknologi Fakultas Pertanian Universitas Respati Indonesia Jakarta \\ Email: ruswadi.msi@gmail.com
}

\begin{abstract}
Abstrak
Kebutuhan tanaman sayuran pakcoy di perkotaan cukup tinggi, namun sayuran ini harus dipasok dari luar kota atau daerah pinggiran. Sempitnya lahan yang tersedia menjadi salah satu penyebab masyarakat perkotaan tidak bisa memproduksi sayuran sendiri. Urban farming merupakan solusi yang tepat untuk mengatasi persoalan keterbatasan lahan. Salah satu teknkologi urban farming yang dapat diterapkan adalah budidaya tanaman secara vertikultur. Faktor utama yang mempengaruhi keberhasilan membudidayakan tanaman sayuran secara vertikultur adalah pupuk yang digunakan. Pupuk pelengkap cair yaitu hasil olahan bahan yang mengandung banyak unsur nutrisi untuk tanaman baik unsur makro maupun mikro yang sangat bagus untuk memperbaiki struktur tanah, menetralkan $\mathrm{pH}$ tanah, memacu pertumbuhan tanaman dimulai pada akar, batang dan daun serta pembuahan guna memaksimalkan hasil produksi tanaman dan mengurangi kerusakan akibat dari serangan hama. Tujuan penelitian ini adalah mengetahui respon tanaman pakcoy terhadap pupuk pelengkap cair pada sistem vertikultur. Bahan-bahan yang digunakan ialah benih green fortune pakcoy hijau, pupuk pelengkap cair, kompos, arang sekam, dan pupuk NPK sedangkan alat-alat yang digunakan adalah polibag, dan rak bambu. Penelitian dilakukan dengan menggunakan Rancangan Acak Kelompok (RAK). dengan jumlah perlakuan 6 dan ulangan 3 (tiga). Dengan jenis perlakuan adalah $\mathrm{P} 1=0 \mathrm{cc} /$ liter air (kontrol); $\mathrm{P} 2=1,5 \mathrm{cc} /$ liter konsentrasi; P3= 2,0 ccl/liter konsentrasi rekomendasi; P4= 2,5 cc/liter konsentrasi rekomendasi; P5 = 3,0 cc/liter konsentrasi rekomendasi; P6 =3,5 cc/liter konsentrasi. Pengamatan dilakukan terhadap data-data yang diuji secara statistik. Variabel penelitian yang diamati adalah jumlah daun, lebar daun, tinggi tanaman, berat segar tanaman, dan berat kering tanaman. Hasil penelitian menunjukkan perbedaan nyata terhadap tinggi tanaman, lebar daun dan jumlah daun tampak setelah tanaman ber umur 21 HST. Perlakuan P4 dengan konsentrasi Pupuk Pelengkap Cair (PPC) 2,5cc/liter air menghasilkan tinggi tanaman, lebar daun, jumlah daun, bobot segar dan bobot kering tanaman pakcoy terbaik.
\end{abstract}

Kata kunci: Urban Farming, Vertikultur, Pakcoy, Pupuk Pelengkap Cair

\section{Abstract}

The need for pakcoy vegetables in urban areas is quite high, however, these vegetables must be supplied from outside the city or outskirt areas. The limited land available is one reason urban communities cannot produce their own vegetables. Urban farming is the right solution to overcome the problem of limited land. One of the urban farming technologies that can be applied is plant cultivation verticulture. The main factor that affects the success of cultivating vegetable crops verticulture is the fertilizer used. Liquid complementary fertilizers, which are processed materials that contain many nutritional elements for plants, both macro and micro elements which are very good for improving soil structure, neutralizing soil $\mathrm{pH}$, spurring plant growth starting at roots, stems and leaves and fertilization to maximize plant production and reduce damage resulting from pests. The purpose of this study was to determine the response of pakcoy plants to liquid complementary fertilizers in the verticulture system. The materials used are green fortune pakcoy green seeds, liquid complementary fertilizers, compost, husk charcoal, and NPK fertilizer, while the tools used are polybags and bamboo racks. The research was conducted using a randomized block design (RBD). with the number of treatments 6 and 3 (three) repetitions. The types of treatment were $\mathrm{P} 1=0 \mathrm{cc} /$ liter of water (control); P2 $=1.5 \mathrm{cc} /$ liter concentration; P3 $=2.0 \mathrm{ccl} /$ liter recommended concentration; P4 $=2.5 \mathrm{cc} /$ liter recommended

http://ejournal.urindo.ac.id/index.php/pertanian

Article History :

Sumbitted 29 Desember 2020, Accepted 30 Desember 2020, Published 31 Desember 2020 


\section{Jurnal Ilmiah Respati}

concentration; P5 $=3.0 \mathrm{cc} /$ liter recommended concentration; P6 $=3.5 \mathrm{cc} /$ liter concentration. Observations were made on statistically tested data. The research variables observed were number of leaves, leaf width, plant height, plant fresh weight, and plant dry weight. The results showed significant differences in plant height, leaf width and number of leaves seen after the plants aged 21 DAS. P4 treatment with a concentration of liquid complementary fertilizer (PPC) of $2.5 \mathrm{cc} /$ liter of water resulted in the best plant height, leaf width, number of leaves, fresh weight and dry weight of pakcoy plants.

Keywords: Urban Farming, Verticulture, Pakcoy, Liquid Complementary Fertilizer

\section{PENDAHULUAN}

Pemupukan merupakan komponen yang sangat penting dalam pertanian, karena pemupukan merupakan salah satu komponen yang dapat meningkatkan hasil yang sangat nyata, terutama untuk tanaman padi. Tetapi pada dewasa ini, petani cenderung berfikiran bahwa semakin banyak memberikan pupuk, maka hasil yang akan di dapat juga akan semakin tinggi. Pada kenyataannya pemberian dosis pupuk yang tidak tepat dapat mengakibatkan biaya produksi yang semakin tinggi tetapi tanaman semakin rawan terserang hama dan penyakit.

Pemupukan secara rasional merupakan upaya meningkatkan efisiensi biaya produksi dan mengoptimalkan peningkatan produksi tanaman. Upaya penggunaan pupuk secara efisien antara lain melalui dosis pemberian pupuk, cara pemberian dan bentuk pupuk yang digunakan secara tepat [1].

Pemupukan merupakan salah satu usahapemberian unsur-unsur hara yang dibutuhkan oleh tanaman untuk menambah persediaan unsur hara di dalam tanah. Pada umumnya pemupukan dilakukan melalui akar, tetapi pemberian melalui daun dan batang juga dapat dilakukan dalam bentuk larutan [2]. Unsur-unsur hara dapat diberikan melalui tanah walaupun tidak diserap seluruhnya oleh tanaman sehingga hasil yang didapatkan terasa kurang menguntungkan, namun penyerapannya akan lebih baik bila ditunjang dengan kesuburan fisik dan kimia yang baik. Khusus untuk unsur hara mikro, jumlah pemupukannya sedikit namun ketersediaanya harus terpenuhi, tidak dapat digantikan dengan unsur hara yang lain.

Pupuk pelengkap cair yaitu hasil olahan bahan yang mengandung banyak unsur nutrisi untuk tanaman baik unsur makro maupun mikro yang sangat bagus untuk memperbaiki struktur tanah, menetralkan $\mathrm{pH}$ tanah, memacu pertumbuhan tanaman dimulai pada akar, batang dan daun serta pembuahan guna memaksimalkan hasil produksi tanaman dan mengurangi kerusakan akibat dari serangan hama [3].

Pada wilayah perkotaan atau perumahan, sempitnya lahan yang tersedia untuk dijadikan lahan pertanian merupakan salah satu permasalahan pertanian saat ini. Ini menyebabkan perlu rekayasa agar di lahan sempit tersebut tetap dapat dihadirkan sayuran organik untuk keperluan hidup sehari-hari. Ketersediaan pangan dalam jumlah yang cukup sepanjang waktu merupakan keniscayaan yang tidak terbantahkan. Setiap rumah tangga diharapkan mampu mengoptimalisasi 


\section{Jurnal Ilmiah Respati}

sumberdaya yang dimiliki, termasuk pekarangan, dalam menyediakan pangan bagi keluarga. Oleh karena itu, Kementerian Pertanian pada awal tahun 2011 menyusun suatu konsep yang disebut dengan Kawasan Rumah Pangan Lestari. Rumah Pangan Lestari erat kaitannya dengan vertical garden yang menggunakan sistem budidaya secara vertikultur. Vertical Garden adalah konsep taman tegak, yaitu tanaman dan elemen taman lainnya yang diatur sedemikian rupa dalam sebuah bidang tegak [4].

Produksi tanaman yang dibudidayakan secara vertikultur dipengaruhi oleh media tanam yang digunakan, dan bahan yang digunakan sebagai wadah vertikultur. Beberapa jenis bahan yang banyak digunakan sebagai media tanam dalam vertical garden adalah sekam bakar, serbuk pakis, cocopeat, moss, pupuk kandang dan lain-lain. Jenis media ini dipilih sesuai syarat tumbuh optimal suatu jenis tanaman [5]. Media tanam yang digunakan dalam penelitian ini ialah tanah, humus, cocopeat dan arang sekam. Sedangkan wadah yang digunakan ialah karung goni, karpet, dan plastik. Interaksi antara media tanam dan wadah vertikultur diharapkan mampu meningkatkan hasil produksi dari tanaman yang dibudidayakan secara vertikultur. Salah satu jenis tanaman yang dapat dibudidayakan secara vertikultur adalah tanaman sawi pakcoy. Pak coy merupakan kerabat dari Caisim dan Sawi, perbedaan mencolok dari ketiganya adalah dari batangnya. Pakcoy memiliki batang yang lebar, besar dan lebih berair. Selain dibuat sayuran, pakcoy juga sering digunakan sebagai asinan maupun dibuat sebagai jus. Di Asia pakcoy dipanen pada berbagai umur, mulai umur pembibitan (2 minggu setelah pindah tanam), masa vegetatif awal, hingga saat baru muncul bunga. Tanaman ini mengandung 93\% air, 3\% karbohidrat, $1,7 \%$ protein, $0,7 \%$ serat, dan $0,8 \%$ abu. Dan merupakan sumber dari vitamin dan mineral seperti ß-karoten, vitamin C, Ca, P, dan Fe [6].

Sawi pakcoy merupakan salah satu komoditas sayuran yang penting di Indonesia. Namun hingga saat ini, produksi sawi belum mampu memenuhi kebutuhan pasar [7]. Hal ini diakibatkan karena rata-rata produksi sawi nasional masih sangat rendah. Potensi hasil sawi dapat mencapai 40 ton/ha, sedangkan rata-rata hasil sawi di Indonesia hanya 9 ton/ha.

Produksi sayuran pakcoy di Indonesia dari tahun 2010 sampai 2013 sebesar 583.770 ton, 580.969 ton, 594.934 ton dan 600.961 ton. Data tersebut menunjukkan bahwa pada tahun 2011 sempat mengalami penurunan hasil produksi tanaman pakcoy. Salah satu penyebab rendahnya tingkat produktivitas tanaman ini adalah masih sedikitnya ketersediaan varietas unggul yang tahan terhadap penyakit berbahaya seperti busuk lunak dan bercak daun, serta masih sedikit sekali varietas yang tahan terhadap suhu panas [8].

Dengan pupuk pelengkap cair dan budidaya secara vertikultur diharapkan dapat meningkatkan produksi tanaman sawi. Penelitian ini bertujuan untuk mengetahui pengaruh pupuk pelengkap cair terhadap 
tanaman pakcoy yang dibudidayakan secara vertikultur.

\section{METODE}

\section{Bahan dan Alat}

Bahan-bahan yang digunakan ialah benih green fortune pakcoy hijau, pupuk pelengkap cair, kompos, arang sekam, dan pupuk NPK sedangkan alat-alat yang digunakan adalah polibag, dan rak bambu.

\section{Rancangan Penelitian}

Penelitian dilakukan dengan menggunakan Rancangan Acak Kelompok (RAK). dengan jumlah perlakuan 6 dan ulangan 3 (tiga). Dengan jenis perlakuan adalah $\mathrm{P} 1=0 \mathrm{cc} /$ liter air (kontrol); $\mathrm{P} 2=1,5 \mathrm{cc} /$ liter konsentrasi; $\mathrm{P} 3=2,0$ $\mathrm{ccl} /$ liter konsentrasi rekomendasi; $\mathrm{P4}=2,5$ cc/liter konsentrasi rekomendasi; P5 $=3,0$ cc/liter konsentrasi rekomendasi; P6 $=3,5$ cc/liter konsentrasi.

\section{Cara Kerja}

Membuat media tanam dimulai dengan mencampur ke tiga bahan tanah, arang sekam dan kompos perbandingan $2: 1: 1$, sesudah bahan teraduk rata bahan media tanam dimasukkan kedalam polibag.

Penyemaian dimulai dari perendaman biji pakcoy dengan air (hangat) selama 1/2 - 1 jam untuk melembabkan kulit benih sehingga pori-pori kulit membesar. Dilanjutkan ke tahap berikutnya yaitu memasukkan benih di tiap lubang tray-semai kemudian ditutup kembali dengan media. Penyiraman persemaian disemprot dengan sprayer jika media mulai kering. Semai ditutup dengan kertas koran supaya tidak terjadi penguapan sehingga media tetap lembab dengan penyimpanan tray semai di tempat sejuk.

Penaman dilaksanakan pada usia benih tanaman pakcoy berumur 15 hari setelah tanam (hst) setelah benih memiliki jumlah dua helai daun pertama. Dari setiap polibag hanya ditanami satu bibit tanaman pakcoy kemudain disusun pada rak vertikultur.

Pemupukan dasar sebelum tanam dilakukan dengan menggunakan pupuk NPK empat hari sebelum tanam dengan dosis 2 gr/polibag. Pemberian konsentrasi pupuk pelengkap cair diberikan setelah tanaman berumur 7 hst, 15 hst, 21 hst, 28 hst, dan 35 hst. Pemberian pupuk pelengkap cair disesuaikan dengan masing-masing perlakuan. Pelaksanaan penyiraman dilakukan setiap hari pagi atau sore hari. dengan takaran volume air yang sama pada setiap perlakuan.

Pemanenan tanaman pakcoy dilakukan setelah tanaman berumur 35 hst dengan cara mencabut seluruh biomasa tanaman serta mencuci akar tanaman pakcoy yang telah dipanen. Selanjutnya menimbang berat segar tanaman pakcoy dan berat kering tanaman yang sudah dikeringkan terlebih dahulu.

\section{Variabel Penelitian}

Pengamatan dilakukan terhadap datadata yang diuji secara statistik. Variabel penelitian yang diamati adalah jumlah daun, lebar daun, tinggi tanaman, berat segar tanaman, dan berat kering tanaman. 


\section{HASIL DAN PEMBAHASAN}

\section{Respon Tinggi Tanaman Pakcoy terhadap Pupuk Pelengkap Cair}

Analisis sidik ragam dan uji BNJ pada taraf $5 \%$ untuk tinggi tanaman menunjukkan adanya pengaruh nyata terhadap tinggi tanaman pakcoy. Perbedaan tinggi tanaman yang cukup signifikan atau berbeda nyata tampak pada perlakuan taraf P4 dengan konsentrasi pada taraf 2,5 cc/liter air. dibandingkan dengan perlakuan lainnya. Perbedaan yang nyata tampak setelah tanaman berumur 21 HST. Pada perlakuan P4 tampak paling tinggi dan berbeda nyata dengan perlakuan lainnya. hal ini karena unsur hara pada perlakuan tersebut dapat terpenuhi dan dapat mendorong atau mendukung proses pertumbuhan tanaman. Respon tinggi tanaman pakcoy terhadap pupuk pelengkap cair dapat dilihat Tabel 1.

Perbedaan tinggi tanaman dapat terlihat setelah tanaman berumur 28 hst. Bobot segar rata-rata tanaman pakcoy pada perlakuan P4 (2,5 cc/liter air) berat bobot segar pada taraf signifikan dibandingkan bobot segar tanaman pakcoy pada perlakuan P1 (kontrol). Pengamatan pada umur 35 Hari Setelah Tanam (HST) menunjukkan rata-rata bobot segar tanaman tertinggi yaitu $(260,07 \mathrm{gr})$ pada perlakuan P4 $\quad(2,5 \mathrm{cc} /$ liter air $)$ dan ratarata bobot segar tanaman terendah yaitu (180,38 gr) pada perlakuan P1 (kontrol).

Tabel 1. Respon tinggi tanaman pakcoy terhadap pupuk pelengkap cair

\begin{tabular}{clllll}
\hline \multirow{2}{*}{ Perlakuan } & \multicolumn{5}{c}{ Tinggi tanaman $(\mathrm{cm})$} \\
\cline { 2 - 6 } & 7 HST & $14 \mathrm{HST}$ & $21 \mathrm{HST}$ & $28 \mathrm{HST}$ & $35 \mathrm{HST}$ \\
\hline P1 & $11,62 \mathrm{a}$ & $18,38 \mathrm{a}$ & $18,38 \mathrm{a}$ & $21,41 \mathrm{a}$ & $21,76 \mathrm{a}$ \\
P2 & $12,22 \mathrm{a}$ & $23,27 \mathrm{a}$ & $23,27 \mathrm{c}$ & $22,94 \mathrm{a}$ & $23,25 \mathrm{~b}$ \\
P3 & $12,00 \mathrm{a}$ & $23,50 \mathrm{a}$ & $23,50 \mathrm{c}$ & $23,50 \mathrm{~b}$ & $23,50 \mathrm{~b}$ \\
P4 & $12,02 \mathrm{a}$ & $26,07 \mathrm{a}$ & $26,07 \mathrm{~d}$ & $25,55 \mathrm{c}$ & $26,03 \mathrm{c}$ \\
P5 & $10,89 \mathrm{a}$ & $23,79 \mathrm{a}$ & $23,79 \mathrm{c}$ & $23,79 \mathrm{~b}$ & $23,79 \mathrm{~b}$ \\
P6 & $10,94 \mathrm{a}$ & $19,97 \mathrm{a}$ & $19,97 \mathrm{~b}$ & $21,33 \mathrm{a}$ & $21,66 \mathrm{a}$ \\
\hline
\end{tabular}

Keterangan: $\mathrm{P} 1=0 \mathrm{cc} /$ liter air (kontrol); $\mathrm{P} 2=1,5 \mathrm{cc} /$ liter konsentrasi; $\mathrm{P} 3=2,0 \mathrm{ccl} /$ liter konsentrasi rekomendasi; $\mathrm{P} 4=2,5 \mathrm{cc} /$ liter konsentrasi rekomendasi; $\mathrm{P} 5=3,0 \mathrm{cc} /$ liter konsentrasi rekomendasi; $\mathrm{P} 6=3,5 \mathrm{cc} /$ liter konsentrasi. Angka yang diikuti huruf yang sama menunjukkan tidak berbeda nyata

Pemberian pupuk melalui daun lebih efektif karena dapat langsung diserap oleh tanaman. Pemberian pupuk melalui daun lebih efektif karena dapat menyerap secara langsung dengan cepat unsur-unsur hara yang di berikan, di samping itu juga menguntungkan karena menghindari kerusakan akar dan dapat menanggulangi kekurangan unsur mikro [9].

\section{Respon Jumlah Daun Tanaman Pakcoy terhadap Pupuk Pelengkap Cair}

Analisis sidik ragam dan uji BNJ pada taraf 5\% untuk jumlah daun tanaman pakcoy menunjukkan adanya pengaruh yang berbeda nyata antara perlakuan terhadap jumlah daun tanaman pakcoy. Respon jumlah daun tanaman pakcoy terhadap pupuk pelengkap cair dapat 
dilihat Tabel 2. Pertambahan jumlah daun yang cukup berbeda nyata pada perlakuan P4 dengan konsentrasi pada taraf 2,5 cc/liter air. sedangkan terendah pada taraf P1 (kontrol). Hal ini karena tanaman telah memperoleh zat zat atau unsur hara makro dan mikro yang dapat mendukung proses pembentukan jaringan daun.

Zat-zat makanan yang diperlukan oleh tanaman hidroponik adalah nitrogen, fosfor, kalsium, magnesium, mangan, sulfur, boron dan seng. Adanya kelebihan dosis yang paling parah dari zat makanan jarang sekali terjadi. Hal ini hampir selain bersifat total kalau tidak segera diperbaiki, namun dapat merusak apabila kelebihan dosis harus benar-benar parah. Hal ini bisa terjadi jika pupuk tidak dicairkan terlebih dahulu [9].

Tabel 2. Respon jumlah daun tanaman pakcoy terhadap pupuk pelengkap cair

\begin{tabular}{cccccc}
\hline \multirow{2}{*}{ Perlakuan } & \multicolumn{5}{c}{ Jumlah daun (helai) } \\
\cline { 2 - 6 } & 7 HST & 14 HST & 21 HST & 28 HST & 35 HST \\
\hline P1 & $5,92 \mathrm{a}$ & $11,33 \mathrm{a}$ & $11,32 \mathrm{a}$ & $13,00 \mathrm{a}$ & $11,42 \mathrm{a}$ \\
P2 & $5,83 \mathrm{a}$ & $10,87 \mathrm{a}$ & $13,37 \mathrm{a}$ & $13,97 \mathrm{a}$ & $14,20 \mathrm{a}$ \\
P3 & $5,67 \mathrm{a}$ & $10,67 \mathrm{a}$ & $13,58 \mathrm{a}$ & $14,17 \mathrm{a}$ & $14,67 \mathrm{a}$ \\
P4 & $5,33 \mathrm{a}$ & $10,77 \mathrm{a}$ & $14,10 \mathrm{a}$ & $15,10 \mathrm{a}$ & $15,53 \mathrm{a}$ \\
P5 & $5,83 \mathrm{a}$ & $10,92 \mathrm{a}$ & $12,92 \mathrm{a}$ & $14,00 \mathrm{a}$ & $14,17 \mathrm{a}$ \\
P6 & $5,42 \mathrm{a}$ & $10,58 \mathrm{a}$ & $12,00 \mathrm{a}$ & $12,92 \mathrm{a}$ & $12,42 \mathrm{a}$ \\
\hline
\end{tabular}

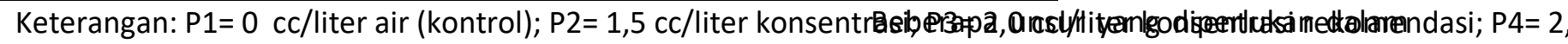

Respon Lebar Daun Tanaman Pakcoy terhadap Pupuk Pelengkap Cair

Analisis sidik ragam dan uji BNJ pada taraf 5\% untuk lebar daun tanaman pakcoy menunjukkan adanya pengaruh nyata terhadap lebar daun tanaman pakcoy. Pertambahan lebar daun yang berbeda nyata pada perlakuan taraf P4 dengan konsentrasi pada taraf 2,5 cc/liter air. dibandingkan dengan perlakuan lainnya. Respon lebar daun tanaman pakcoy terhadap pengaruh konsentrasi pupuk pelengkap cair dapat dilihat Tabel 3. proses pertumbuhan tanaman telah diperoleh melalui akar maupun daun yang meliputi unsur unsur hara makro dan mikro sehingga dapat mendukung pembentukan jaringan daun. Unsur hara makro dan mikro diberikan melalui daun dengan cara penyemprotan. merupakan pupuk daun lengkap. berbentuk cair dengan kandungan kadar $\mathrm{N} 11 \%, \mathrm{P}_{2} \mathrm{O}_{5} 10 \%$ dan $\mathrm{K}_{2} \mathrm{O} 6 \%$ serta unsur-unsur hara lainnya yang saling melengkapi [10]. 


\section{Jurnal Ilmiah Respati}

Tabel 3. Respon lebar daun tanaman pakcoy terhadap pupuk pelengkap cair

\begin{tabular}{clllll}
\hline \multirow{2}{*}{ Perlakuan } & \multicolumn{5}{c}{ Lebar daun (cm) } \\
\cline { 2 - 6 } & 7 HST & 14 HST & 21 HST & 28 HST & 35 HST \\
\hline P1 & $4,62 \mathrm{a}$ & $7,96 \mathrm{a}$ & $8,34 \mathrm{a}$ & $8,65 \mathrm{a}$ & $7,42 \mathrm{a}$ \\
P2 & $4,62 \mathrm{a}$ & $8,05 \mathrm{a}$ & $9,85 \mathrm{a}$ & $10,19 \mathrm{a}$ & $1,51 \mathrm{a}$ \\
P3 & $4,65 \mathrm{a}$ & $7,68 \mathrm{a}$ & $10,08 \mathrm{a}$ & $10,37 \mathrm{a}$ & $1,56 \mathrm{a}$ \\
P4 & $4,48 \mathrm{a}$ & $8,09 \mathrm{a}$ & $11,97 \mathrm{~b}$ & $12,17 \mathrm{~b}$ & $1,40 \mathrm{a}$ \\
P5 & $4,84 \mathrm{a}$ & $7,75 \mathrm{a}$ & $10,02 \mathrm{a}$ & $10,17 \mathrm{a}$ & $1,37 \mathrm{a}$ \\
P6 & $4,19 \mathrm{a}$ & $7,43 \mathrm{a}$ & $8,47 \mathrm{a}$ & $8,78 \mathrm{a}$ & $8,40 \mathrm{a}$ \\
\hline
\end{tabular}

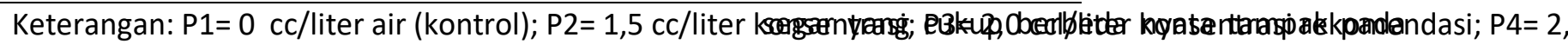

\section{Respon Bobot Segar Tanaman Pakcoy terhadap Pupuk Pelengkap Cair}

Analisis sidik ragam dan uji BNJ pada taraf $5 \%$ untuk bobot segar tanaman pakcoy menunjukkan adanya perbedaan nyata terhadap bobot segar tanaman pakcoy jika dibandingkan dengan perlakuan lainnya. Bobot

\begin{tabular}{ccc}
\hline Perlakuan & Rata-rata (gram) & Notasi \\
\hline P4 & 313,00 & A \\
P5 & 280,83 & $\mathrm{a}$ \\
P3 & 267,53 & $\mathrm{a}$ \\
P2 & 247,33 & $\mathrm{a}$ \\
P6 & 241,27 & $\mathrm{a}$ \\
P1 & 213,87 & $\mathrm{~A}$ \\
\hline
\end{tabular}

Keterangan: $\mathrm{P} 1=0 \mathrm{cc} /$ liter air (kontrol); $\mathrm{P} 2=$ maka akan dapat meningkatkan pertumbuhan $1,5 \mathrm{cc} /$ liter konsentrasi; P3= 2,0 dan perkembangan tanaman yang $\mathrm{ccl} /$ liter konsentrasi rekomendasi; bersangkutan. Selain itu, konsentrasi $2.5 \mathrm{cc} /$ liter $\mathrm{P} 4=2,5 \mathrm{cc} /$ liter konsentrasi rekomendasi; P5 $=3,0 \mathrm{cc} /$ liter konsentrasi rekomendasi; $\mathrm{P} 6=3,5$ cc/liter konsentrasi. Angka yang diikuti huruf yang sama menunjukkan tidak berbeda nyata.

Jumlah unsur hara yang diberikan cukup untuk memenuhi kebutuhan tanaman air ternyata merupakan konsentrasi yang tepat sehingga proses absorpsi lewat daun dapat dilakukan dengan optimal. Seperti diketahui, penyerapan unsur hara melalui daun sangat berkaitan dengan permeabilitas membran. Hal ini dikarenakan mekanisme penyerapan unsur hara oleh daun merupakan proses difusi dan untuk unsur-unsur hara tertentu melalui mekanisme transpor aktif [11]. Pupuk selain dapat diberikan melalui tanah juga dapat 
diberikan melalui daun tanaman. Proses penyerapan hara makro dan mikro yang diberikan lewat daun lebih cepat jika dibandingkan dengan pemupukan melalui tanah. Hilangnya pupuk karena tercuci, penguapan, dan terfiksasi akan lebih kecil karena pupuk dapat langsung diserap tanaman [10].

Keuntungan pemakaian pupuk daun adalah tanaman lebih cepat mengeluarkan tunas serta tanaman tidak mudah rusak dan pemupukan melalui daun pada musim kering lebih efisien karena pupuk yang diberikan melalui daun sudah dalam keadaan siap diabsorpsi, sehingga langsung diserap oleh daun tanaman [12]. Selain itu, pemupukan lewat daun tidak dipengaruhi oleh kondisi pH dan air tanah. Ketidak hadiran salah satu unsur hara makro dan mikro dapat menyebabkan terganggunya pertumbuhan tanaman [13].

\section{Respon Bobot KeringTanaman Pakcoy terhadap Pupuk Pelengkap Cair}

Analisis sidik ragam dan uji BNJ pada taraf 5\% untuk bobot kering tanaman pakcoy menunjukkan adanya pengaruh nyata terhadap bobot segar tanaman pakcoy. Bobot kering yang cukup signifikan pada perlakuan taraf P4 dengan konsentrasi pada taraf 2,5 cc/liter air sedangkan terendah pada taraf P1 (kontrol).
Respon bobot segar tanaman pakcoy terhadap pupuk pelengkap cair dapat dilihat Tabel 5 . Bobot kering rata-rata tanaman pakcoy pada perlakuan P4 (2.5 cc/liter air) berat bobot kering pada taraf signifikan dibandingkan bobot segar tanaman pakcoy pada perlakuan P1 (kontrol). Umur pengamatan 35 hst rata-rata bobot kering tanaman tertinggi yaitu $(260,07$ gr $)$ pada perlakuan P4 $(2,5 \mathrm{cc} /$ liter air) dan rata-rata bobot segar tanaman terendah yaitu $(180,38 \mathrm{gr})$ pada perlakuan P1 (kontrol).

Hal ini menujukkan bahwa pengaruh perlakuan yang bedanyata tampak pada peroses pembentukan jaringan tanaman setelah kadar air dalam sel hilang atau sangat kecil. Jika jumlah unsur hara yang diberikan cukup untuk memenuhi kebutuhan tanaman maka akan dapat meningkatkan pertumbuhan dan perkembangan tanaman yang bersangkutan. Selain itu, konsentrasi 2,5 cc/liter air ternyata merupakan konsentrasi yang tepat sehingga proses absorpsi lewat daun dapat dilakukan dengan optimal. Seperti diketahui, penyerapan unsur hara melalui daun sangat berkaitan dengan permeabilitas membran. Hal ini dikarenakan mekanisme penyerapan unsur hara oleh daun merupakan proses difusi dan untuk unsur-unsur hara tertentu melalui mekanisme transpor aktif [11].

Tabel 5. Respon bobot kering tanaman pakcoy terhadap pupuk pelengkap cair

\begin{tabular}{ccc}
\hline Perlakuan & Rata-rata (gram) & Notasi \\
\hline P4 & 26,03 & A \\
P5 & 23,79 & a \\
P3 & 23,50 & a \\
P2 & 23,25 & a
\end{tabular}




\begin{aligned} P6 & 21,76 \\ P1 & 21,66 \\ \hline Keterangan: & P1= 0 cc/liter air (kontrol); P2= \\ & $1,5 \mathrm{cc} /$ /iter konsentrasi; P3= 2,0 \\ & $\mathrm{ccl} /$ liter konsentrasi rekomendasi; \\ & P4= 2,5 cc/liter konsentrasi \\ & rekomendasi; P5 = 3,0 cc/liter \\ & konsentrasi rekomendasi; P6= 3,5 \\ & cc/liter konsentrasi. Angka yang \\ & diikuti huruf yang sama \\ & menunjukkan tidak berbeda \\ & nyata. \end{aligned}

SIMPULAN

Hasil penelitian dapat disimpulkan bahwa pupuk pelengkap cair konsentrasi 2,5cc/liter air memberikan tinggi tanaman, lebar daun, jumlah daun, bobot segar dan bobot kering tanaman pakcoy yang paling baik.

\section{DAFTAR PUSTAKA}

Landon, J. R. 1984. Tropical Soil Manual. Booker Agriculture International Limited. LondonEngland. pp: 133-137.

Haryadi, S. S. 1989. Pengantar Agronomi. Gramedia. Jakarta.

Subagio. 2015. Pupuk Daun Grow More Untuk Hasil Terbaik. http://www.tokoagri.com/pupukdaungrow-more/. Diakses pada Kamis, 16 Maret 2017.

Saptana, S., dan Friyatno, 2013. Prospek Model Kawasan Rumah Pangan Lestari Dan Replikasi

Pengembangan KRPL. J. Forum Penelitian Agro Ekonomi. 31 (1): 67-87. a

Noverita, S. 2005. Pengaruh Konsentrasi Pupuk Pelengkap Cair Nipkaplus dan Jarak Tanam Terhadap Pertumbuhan dan Produksi Tanaman Baby Kaylan (Brassica oleraceae L.) Secara Vertikultur. J. Penelitian Bidang Ilmu Pertanian, 3 (1): 21-29.

Aini, N. 2013. Pengaruh Pemberian Bokashi Kulit Pisang (Musa Paradisiaca L.) dengan Penambahan Aktivator EM4 Terhadap Pertumbuhan dan Hasil Tanaman Sawi Pak Choy (Brassica Rapa L.). [Skripsi].

Cahyono, B. 2003. Teknik dan Strategi Budidaya Sawi Hijau. Yayasan Pustaka Nusatama. Yogyakarta. Hal: 12-62.

Susilo. 2016. Peluang Usaha dari Budidaya Sawi Pak Coy. Javalitera. Jakarta.

Lingga. P., dan Marsono. 2008. Petunjuk Penggunaan Pupuk.Penebar Swadaya. Jakarta.

Sutejo. M. M. 1995. Pupuk dan Cara Pemupukan. Rineka Cipta. Jakarta.

Salisbury. F.B., and C.W. Ross. 1992. Plant Physiology. Wadsworth Publishing Company. Belmont. California.

Sujatmika. 1988. Keuntungan Pemupukan Lewat Daun. Trubus 225 Tahun XIX. Jakarta.

Dwijoseputro. 1983. Pengantar Fisiologi Tumbuhan. Gramedia. Jakarta. 